\title{
Reflection on the theory of the Arab origin of the Yoruba people
}

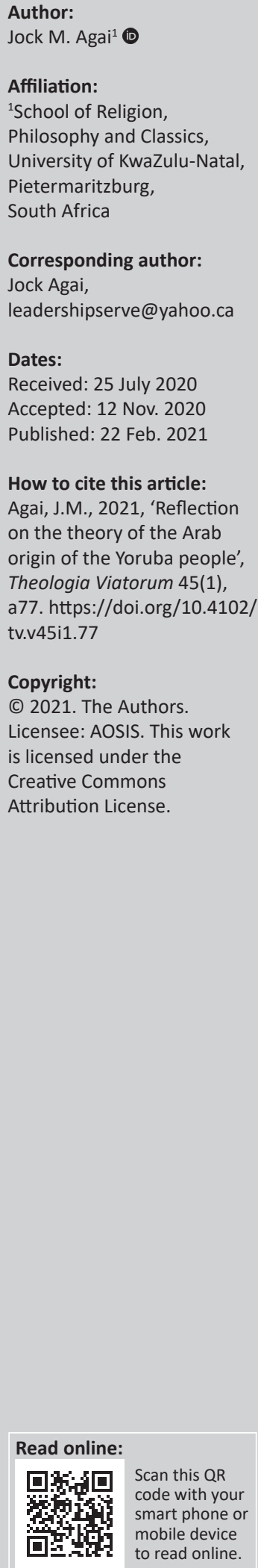

\begin{abstract}
The theory of the Arab origin of the Yoruba people is seemingly the oldest amongst other theories of their origins. This is because the original Yoruba oral tradition pertaining to their origin subscribes to the 'East' as the location of their origin. The East is believed to be Arabia or Mecca. There are many reasons why scholars from the 19th to the 21st centuries dissociated themselves from the Arab theory of the Yoruba origin, yet some scholars uphold the theory in high esteem. The religions of Christianity and Islam might have influenced the interpretation of the Arab theory of the Yoruba origin. This research elucidates the Arab theory of the Yoruba origin pointing at the historical circumstances that might have led to the acceptance and the non-acceptance of the theory by various people who are interested in the writing of the Yoruba history. The aim of the research was to highlight the discrepancies or the weaknesses of the theory to initiate further research on the subject.
\end{abstract}

Keywords: Arabia; Christians; coptic; east; Egypt; Islam; Mecca; Oduduwa; Yorubaland.

\section{Introduction}

The Yoruba people are some of the most widely distributed ethnic groups across many parts of West Africa. They are known to occupy some major parts of Nigeria, Togo and Benin Republic as indigenes. In Nigeria alone, there are over 40 million Yoruba-speaking people (Ayandele 2004:121). The Yorubas are distributed all over Nigeria. Officially, they are indigenes of the western parts of Nigeria comprising Lagos, Ekiti, Ogun, Ondo and Oyo states. They also share two states, Kogi and Kwara, in north-central parts of Nigeria (Aliogo 2012:20-26). Other distinguishing features of the Yorubas are: their religion is likely to have influenced many people in the Caribbean and the North and South Americas (Awolalu 1979:xiii); they take pride in the acquisition of formal education (Akintoye 2004:2-3; Ayandele 2004:121); they are highly prolific and their history is the most researched one amongst all other ethnic groups in sub-Saharan Africa (Lange 2011:39); and their history is one of the most well-preserved, institutionalised and widely taught amongst all the native ethnic groups (Afolayan 1993:32; Akintoye 2004:3).

Despite the progress the Yorubas have made in preserving and documenting their history, the history of their origin remains one of the most contested and an obscure one (Akintoye 2004:3; Johnson 1921:3). Different scholars have suggested the origins of the Yoruba to be from different parts of the world, especially the ancient Near East. In 1812, Mohammed Belo taught about the Arab origin of the Yorubas (Muhammad 2013:19), whilst Samuel Johnson around the 1890s taught that the Yorubas might have originated from amongst the Coptic Egyptians, or from Nubia. He attempted to dissociate the Yoruba origin from Arabia or Islam (Johnson 1921:5).

Furthermore, around 1910 to 1912, Leo Frobenius taught that the Yorubas and their culture might have been influenced or probably originated from Etruria and North Africa in what he described as the 'Atlantic' theory of the Yoruba origin (Frobenius 1913:345). Olumide Lucas in 1948 suggested a pre-dynastic Egyptian and a possibly Christian origin of the Yoruba (Lucas 1948:352; Olupona 1993:242), whilst Samuel Ajayi Crowther and Father J.J. Williams associated the Yoruba origin with Israel (Lucas 1970:382; Oyebade 2004:51). Agai suggested that the Yorubas might have originated from within West Africa or from Nigeria itself in what he calls 'the theory of the local origin of the Yoruba' (Agai 2016:189-190).

The first Nigerian and non-Yoruba known to have documented the history of the Yoruba origin is Mohammed Belo. However, it is important to note that he did not invent the theory of the Arab origin of the Yorubas (Muhammad 2013:19). The most prominent Yoruba tradition that describes the history of their origin is that of the Oduduwa as a migrant legend who is said to have originated from Mecca and landed in Ile Ife (Omolewa 2008:54-55). Wesley Mohammad, 
a scholar in Islamic and Near Eastern Studies, is adamant that the Yorubas and strictly those of Oyo descent, originated in Arabia. He attempted to provide some extensive historical evidence towards his claim that the Oyo Yorubas are of Arabian descent (Muhammad 2013:3-34). Even when the Yoruba origin is associated with the Kingdom of Meroe in ancient Sudan, the alleged Arab influence on the Yorubas cannot be excluded in this regard (Folorunso 2003:87). This is one of the reasons why the Arab theory of Yoruba origin needs to be studied.

Moreover, Samuel Johnson is one of the first Yoruba people who, despite not having a university degree, documented the Yoruba oral history in its broader and most comprehensive form. His views on Yoruba history are highly respected, is incontestable and regarded as sacred by many of the Yorubas (Akintoye 2004:3; Falola 1999:33-34). ${ }^{1}$ He interviewed many Yoruba leaders, elders and the royal bards or arokins who worked in the king's palace especially in Oyo. The arokins served the Alaafin (king) of Oyo as oral traditionalists, historians and musicians (Johnson 1921:viii; Muhammad 2013:5). Johnson also said that at the palace of the Oyo king, there were bards, the king's drummers and cymbalists whom he relied upon to obtain information regarding the Yoruba origin: '[i]t is on them we depend as far as possible for any reliable information we now possess' (Johnson 1921:3).

Johnson said that the Yoruba oral tradition connected the Yoruba origin with the 'East' and that many Yoruba people especially those he interviewed thought that the East meant Arabia or Mecca: '[t]he Yorubas are said to have sprung from Lamurudu, one of the Kings of Mecca ...' (Johnson 1921:3). However, Johnson contested the general association of the East with Mecca. He said that the East might have meant Egypt and not Mecca. He further expressed the view that the Yorubas are not of Arabian origin: '[ $t$ ]he Yorubas are certainly not of the Arabian family, and could not have come from Mecca...' (Johnson 1921:5).

Many other prominent writers of the Yoruba history are mostly Christians, such as Olumide Lucas, Toyin Falola, Folorunso, Leo Frobenius and many others, and they seemed not to favour the Mecca, or Arab theory of the Yoruba origin. Olojede said that the Arab theory of the Yoruba is not favourable to many scholars. She quoted Beier Law who taught that the association of the Yoruba origin with the East in connection with Mecca is a fanciful way of associating the Yoruba people with the civilisations of the East (Olojede 2011:344). Muhammad, on the other hand, blamed Johnson for his Christianisation of the Yoruba history. He is of the view that the arokins Johnson interviewed between 1887 and 1897 were neither Christians nor Muslims, and that the rise of Islam in Yorubaland in the 18th and 19th centuries did not directly affect the writing of the Yoruba

1.At this juncture, it may be relevant to point out that the first Yoruba man with university degree to have written the Yoruba history is Prince Adeyemi, who in 1914 universted de 1914 published I we Itan Oyo-lle ati Oyo Isisilyi abi Ago-d" Oyo 'A History of the Old and New Oyo. He obtained a bachelor of arts in the Classics in 1911 from Fourah College, Sierra Leone. Wesley Muhammad said that Prince Adeyemi believed that the Yorubas of the Oyo extraction originated from Medina, in the East (Muhammad 2013:11). history the way Johnson insinuated. In other words, Muhammad believed that there is an Arabian influence on the Yorubas (Muhammad 2013:9).

The earliest records or oral tradition pertaining to the Yoruba history noted by Belo, Johnson and Adeyemi linked the Yoruba origin with Arabia (cf. Muhammad 2013:11) despite which many other scholars recently refused to accept the Arab theory of the Yoruba origin. There is therefore a need to study the theory of the Arab origin of the Yoruba to ascertain the circumstances that led to the creation of the theory. This research is a study of the Arab origin of the Yoruba, and the probable circumstances that might have motivated scholars to associate and disassociate the Yoruba origin from Arabia.

Furthermore, in this research, there is a deliberate attempt to concentrate on the views of Samuel Johnson and those of Wesley Muhammad. This is important because the two authors give seemingly opposite views about the Arab theory of the Yoruba. My argument is that the theory of the Arab origin of the Yoruba is not absolute as claimed by some, but the theory is full of discrepancies, which I have questioned. My argument aims to initiate further debate and to inspire scholars who are interested in the subject to begin to or to continue to investigate the alleged migration routes, the chronological order and the cultural connectedness between the post-Islamic Arabians and the Yorubas of Nigeria.

\section{The development of the theory of the Arab origin of the Yoruba}

The Yorubas have a tradition according to which there were Arabs who migrated from Arabia to live in Yorubaland (Olojede 2011:343-344). The tradition of associating the origin of the many West African people with Arabia and the ancient Near East has been an old tradition. In the 9th century, Arab geographers such as al-Ya ${ }^{\complement} q u \bar{u} \bar{I}$ and Ibn Qutayba, both of whom were Iraqis, together with the 10th-century Iraqi writer al-Mas ${ }^{\complement} \bar{u} d \bar{I}$ said that the people of West Africa originated from Arabia and the ancient Near East (Lange 2011:583). More so, al-Ya ${ }^{\complement} q u \bar{u} b \bar{I}$ in $T a^{\prime} r \bar{I} k h$ (history book) written in 873 associated the origins of the West African people with the ancient Near East. Some Arabs like al-Ya $\mathrm{a}^{\complement} q u \bar{b} \bar{I}$ were of the view that Ham, one of the sons of Noah, was regarded as the ancestor of the African or black people, and whose descendants were cursed to serve as slaves (cf. Hunwick n.d.:7-24; cf. Gen. 9). Lange (2011) quotes al-Ya $a^{\uparrow} q u \bar{b} \bar{I}$, who observed that the black people of West Africa originated from the ancient Near East through Ham:

The people of the progeny of Hām, son of Noah, left the country of Babel, went to the west, crossed the Euphrates, continued to Egypt and thence moved to East and West Africa of the Nile the Zaghawa settled in kanem [in northern Nigeria], next the Hausa (text: HWDN), then the Kawkaw and finally the people of Ghana. (p. 580). 
It is not known precisely when and how some Arabs came to believe that West Africans originated from Arabia or the ancient Near East, but it is assumed that the Hamitic hypothesis may have influenced this line of thought. The Hamitic myth or hypothesis is a view that human civilisation is not initiated by black people or people of African progenies. The myth posits a view that African innovations and technologies did not originate from Africa but the Hamites, a Caucasian race. The myth creates a perception according to which Africans did not originate in Africa, but were from some regions of the ancient Near East and descended from some people assumed to be of a superior race (Agai 2016:201-202).

Similarly, the view of associating the origin of West African from some foreign places might have both local and foreign sources. For the moment, I am not denying the possibility that there could be historical facts relating to the people of West Africa having originated from some foreign countries and yet, it is quite possible that they originated locally. Dierk Lange noted that al-Ya $a^{\varsigma} q u \bar{b} \overline{\mathrm{I}}$, who wrote about the migration of the ancient Near Eastern peoples to West Africa, learnt of this conviction from the West Africans themselves: a belief that Lange himself might not have been certain of, expressing his doubts in his observation. This is why it can be suggested that al-Ya $a^{\uparrow}$ ūbI might have been influenced by the Hamitic myth (Lange 2011):

As for al-Ya`qūb $\bar{I}$, his brief account of the great migration of West African people started from Babylon relies probably on West African oral traditions reported by Arab traders, which in his time might have been more detailed than now. (p. 584)

It might be recalled that Mohammed Belo, born on 03 November 1781, was a prominent Islamic leader in northern Nigeria (Quadri 1986:53). His father Uthman dan Fodio was the first to Islamise northern Nigeria through Islamic jihad. After the death of his father in 1817, Belo took over the military operation of his father's followers. He established more Sharia courts within the Sokoto caliphate and extended jihad to northern Cameroun, Mali, Senegal and Burkina Faso (Amy 2016:2). Belo was brilliant and he studied various subjects including Arabic, rhetoric and classical Islamic systems. He was trained by Abdullah Fodio his uncle, Muhammad Sa ${ }^{\complement} \mathrm{d}$ his elder brother and Uthman dan Fodio his father (Agai 2015:431).

Belo's prominence enabled him to meet distinguished people who visited northern Nigeria. For example, he met a British envoy to Sokoto, Captain Hugh Clapperton in 1824 to discuss the implementation of the abolition of transAtlantic slave trade (Clapperton, Denham \& Oudney 1826:339; Kolapo 2010:72). His interest in religion, trade, politics and history would have empowered him to meet people from Arabia and other parts of the world who visited Nigeria. It was a tradition amongst many African countries including Nigeria that officials or people visiting a region of a country had to interact or meet the local chief or community head for approval, before embarking on their assignments. This might have accorded Belo the opportunity to meet the Arab and Islamic preachers from the Near East, Mali and North Africa who might or might not have influenced his thoughts on the Arab origin of the Yorubas (cf. Omolewa 2008:90-93). Before he died in Wurno, Sokoto in 1837 (Quadri 1986:54), Belo associated the Yoruba origin with Iraq. In InfaqulMaysur published in 1812, Lange (2011) quoted Belo who said that the Yoruba ancestors came from Iraq, an Arabian country:

The Yoruba were remnants of the Canaanites of the tribe of Nimūd who were expelled from Iraq by Ya $a^{\varsigma} u b$ b. Qahtān and who fled to the west before they proceeded via Egypt and Ethiopia until they came to Yoruba. (p. 583)

Furthermore, in the same book Infaqul-Maysur, Belo noted that the original Yoruba ancestors were the Canaanites, the descendants of Nimrod who left Arabia because of some internal conflicts that led to their persecution until they arrived at Yorubaland (Johnson 1921:5-6; cf. Muhammad 2013:19). After Belo, many more Yorubas and writers of the Yoruba history have continued to associate the Yoruba origin with Arabia. Along with Belo's writings and the Yoruba oral tradition that linked the Yoruba origin with the East, it may be suggested that the presence of Islamic preachers from North Africa in Nigeria and the writings of the early Arabs who had contact with West Africa in the 9th century, continued to influence the 18th-, 19th- and the 21st-century writers of Yoruba history (cf. Falola \& Heaton 2010:29; Omolewa 2008:90-93).

It is therefore not surprising that Geoffrey Parrinder believed that the Yoruba culture has some similarities with the customs of the Arab people. He suggested that the Yoruba culture might have originated from Arabia and by implication the Yoruba people as well (Parrinder 1951:205-209). Opeloye is of the view that the traditions surrounding Yoruba marriages are similar to the one prescribed according to Islamic injunctions. He believed that many Yoruba customs are similar to those of Islam (Opeloye 2011:4-8).

Similarly, Dr Saburi Oladeni Biobaku believed that the Yoruba culture could not be separated wholly from the culture of the Arabians. He is of the view that it does not matter where the Yorubas originated: whether Egypt or Israel or Etruria or Meroe or Yemen, what is significant for him is that the Arabs influenced the Yoruba: '... the Yoruba came under Arab influences in their old home, and their subsequent migration was connected with Arab movements' (Biobaku n.d.:63-64). Yoruba people like Biobaku do not support the theory of the local origin of the Yoruba. He may have believed amongst others that the Yorubas originated, and were presumably influenced by some superior races from the ancient Near East, mainly the Arabs. Therefore, the Arab theory of Yoruba origin could have originated from anywhere within West Africa or outside of West Africa; a theory further disseminated by both West Africans and non-West Africans alike. 


\section{The contribution of Oduduwa to the development of the theory of the Arab origin of the Yorubas}

The Yoruba oral tradition regarding their origin is centred on Oduduwa, the alleged ancestor of all the Yoruba people. There are two major categorisations of Oduduwa: firstly, Oduduwa has been described as a supernatural being said to have been banished from heaven by Olodumare (God) and landed in Ile Ife with the help of an iron chain. He came along with a cock, soil and a palm kernel. He threw the soil onto the Earth that was naturally full of water, and the soil became a landmass (Ojo 1999:5). Many Yorubas including Samuel Johnson did not favour this tradition of the descending of Oduduwa from heaven. Samuel Johnson rather emphasised the Coptic and the Christian, or the biblical view of the Yoruba origin, which ascribed creation to God alone as narrated in the book of Genesis (Johnson 1921:5-7; cf. Olupona 1993:242).

The second categorisation of Oduduwa pertained to his identity as a migrant legend that originated from the 'East' and came to Ile Ife, whilst his two children went westward to Gogobiri and Kukuwa in northern Nigeria (Ojo 1999:5-6). According to the legend, Oduduwa, a prince and a son to the king of Mecca called Lamurudu, rejected Islam that was his religion by birth and supported idolatry. He succeeded in converting one of the mosques in Mecca to a place of idol worship. He had followers who revolted against some Muslims in Mecca, leading to the death of his father Lamurudu. Oduduwa together with his sons and a few followers were exiled from Mecca (Johnson 1921:4; Ojo 1999:5). Sahibu, an Islamic loyalist from Mecca, ran after Oduduwa for revenge, and to destroy him for his apostasy. Sahibu came armed with a copy of the Koran from Mecca, but was defeated by Oduduwa and his soldiers, and the copy of the Koran was taken from him and kept in a temple in Ile Ife (Ojo 1999:5).

Furthermore, the Koran taken from Sahibu, now called Idi (something tied up), was apparently worshipped in Yorubaland up to the time of Samuel Johnson. Oduduwa came to Ile Ife and met people there, including Agboniregun (Setilu) who was said to be the founder of Ifá worship (Johnson 1921:4). Amongst other people from various tribes that Oduduwa met in Ile Ife was the Igbos (Muhammad 2013:28). The names of kings such as Opereti, Enewe, Awurebe and Omogberaye are a reminder to Yoruba historians that Oduduwa met people living in Yorubaland when he came, and he and his followers were kept in a place called 'strangers' quarters' in Ile Ife (Ayandele 2004:123). Johnson (1846-1901) might have thought that Belo (1781-1837) was the first person to propose the notion of connecting the 'East' with Arabia regarding the Yoruba origin (Johnson 1921:5-6). Johnson said Oduduwa came from the East; that he lived, died and was deified in Ile Ife (Johnson 1921:143).
The East was associated with Mecca in Saudi Arabia, or Meroe in Sudan. Folorunso said that for the Yorubas, 'the East is Mecca, and Mecca is the East' (Folorunso 2003:85). Johnson, who seemed to be one of the first Yoruba indigenes to document the Oduduwa oral tradition, was told that the Yorubas originated from the East. He claimed to believe that the Yorubas originated from the East but to him, the East did not mean Mecca or Arabia, but Egypt. He said that the Arabs did not have a history of migrating to reside in Nigeria and that if they did, there was no record of such a migration:

[...T] hat the Yorubas came originally from the east there cannot be the slightest doubt, as their habit, manners and customs, etc., all go to prove ... the Yorubas are certainly not of the Arabian family, and could not have come from Mecca universally known in history, and no such accounts as the above are to be found in the records of Arabian writers of any kings of Mecca.... (Johnson, 1921:5)

It is not known precisely why and when the Yorubas began to associate the history of their origin with the East. Many ethnic groups in Nigeria also believed that they originated from the East. For example, the Miship people of Jibam, comprising over 10000 people in north-central Nigeria believed that the ancestor, Mwankan, originated from the 'East'. In popular belief amongst the Miship people, east meant Egypt. ${ }^{2}$ There could be many speculative reasons that might have prompted the Yoruba people to associate the history of their origin with the East, quite like the Miship people. Major religions like Islam, Christianity and Judaism all originated from the ancient Near East and the West African people could have been attracted to the word 'East' because it is linked to these religions. Even Egypt itself is located in North-East Africa still linked to the word 'East' (O'Connor \& Reid 2003:11).

The Hamitic myth might also be another reason why some Africans preferred to associate their origin with the East (cf. Agai 2016:201). Moreover, some Christians are of the view that the Messiah came from the East: 'there is a generalization that the message of the Messiah came from the east proclaimed by Jewish individuals into Egypt and Africa' (Sundkler \& Steed 2000:7-9). They likely use the concept of the East where the sun rises, as a metaphor to describe their origin (Agai 2016:198).

In addition, there is the view according to which human civilisation started in the Middle East or the Near East (Oates 1979:11; Pate \& Hays 2003:21-22), which could be said to be synonymous with the Arabian Peninsula, or the region occupied by the Arabs and their descendants also called the 'Middle East' (United Church of God 2007:4-5).

2.On 04 June 2020 , some scholars travelled to Jibam to interview the oldest people living in Jibam and to trace the migration of Mwankan, who is allegedly the original ancestor of the Miship people from Jibam. It would probably be the first time that the history of the Jibam people was being officially written from historiographica perspectives. The research team was headed by Dr Agai M. Jock (University of perspectives. The research team was headed by Dr Agai M. Jock (University of KwaZulu-Natal). Other team members are Eugene Musa Dido (Plateau State University, Bokkos), Peace Danjuma (Plateau State University, Bokkos) and Chimkaodinaka David Chiwem (University of Jos). The Jibam elders said that they originated from the East which to them came to Lake Chad from Egypt and passed by Maiduguri in Borno state from where they finally migrated to Jibam in Plateau State of north-central Nigeria (J.M. Agai, 2020 , Interview on 'the history of the Miship people of Jibam', 04 June). 
It was generally felt that the Yorubas took pride in linking their history to the East. The controversial aspect of this subject pertained to the specific meaning of 'East'. Initially, in the Yoruba oral tradition, the East was regarded as Mecca or Arabia, and even the Kingdom of Meroe in Sudan. In the process of investigating the Arabs' influence on Yorubaland, scholars began to question the exact location of the East. Johnson, Folorunso and others thought that the East meant Egypt, but Belo and the Arabs who came to Yorubaland might have opined that the East meant Mecca or Arabia or Iraq.

Moreover, there are two major points that need to be noted regarding the role of Oduduwa in the development of the Arab theory of Yoruba origins: firstly, his identity or personality and secondly, his origin or the location from which he came. Though Samuel Johnson described Oduduwa as a human being who lived in Ile Ife, died and was buried there (Johnson 1921:143), he appears to have downplayed the role of Oduduwa as a literal human being. He might have referred to Oduduwa as a human being because of the narrative style, or else he mistook the name as one referring to multiple people. He refers to Oduduwa as a 'mythical personage' (Johnson 1921:143), suggesting that Oduduwa might not have been a real person, and even if he was, it would probably have been in a commonplace myth. Also, Johnson underplayed the Yoruba myth that referred to Oduduwa as a creator, and instead he promoted the biblical view that refers to God as the creator. His emphasis on the Coptic origin of the Yoruba is another reason why it can be argued that he downplayed the role of Oduduwa as a person from whom the Yoruba people descended: Johnson failed to connect Oduduwa with the Coptic Christians (Johnson 1921:6-7). Johnson's Christian background and the need for him to promote his Christian faith overshadowed his interpretation of the Yoruba origin, which led him to underplay Oduduwa as a single ancestor of the Yoruba people (Agai 2016:137-143).

Wesley Muhammad argued that Oduduwa met the Igbos and other ethnic groups that lived in Yorubaland when he came, and that it was impossible for Oduduwa to subdue the people he found in Yorubaland. This led to a compromise that resulted in the formation of the 'Yoruba' people. He further mentioned that the name 'Oduduwa' is not of Arabic origin, but a Sudanese name. He believed that Oduduwa might not have been the ancestor of the OyoYoruba people. Muhammad believed in the possible migration of the apostates (those that rebelled against Islam in Arabia in the 7th century) from Arabia to Yorubaland, but he argued that Oduduwa was not amongst them: '[i]t is also the case, however, that "Oduduwa" was not actually the name of the leader of the seventh century migration into Yorubaland' (Muhammad 2013:28). Ayandele also noted that the Oduduwa legend should not be used to define the direct origin of the Yoruba people. Instead, the legend aims to emphasise that a prosperous kingdom reigned supreme in Yorubaland during the time of Oduduwa (Ayandele 2004:123).
The Yoruba oral tradition that ascribes the Yoruba or the Oduduwa origin from Mecca has also been questioned by several scholars who prefer not to singularise Oduduwa but pluralise his personality. It thus suggests that a group of people, more numerous than just Oduduwa and his sons, might have migrated to Yorubaland from the Near East, or from Arabia. Johnson's emphasis was on a possibly sizable number of people - not just Oduduwa and his sons migrated to Yorubaland and were the ancestors of the Yoruba people by using the phrase '...that they sprung...' and '...that they were...' (Johnson 1921:6-7). Although Mecca is in Arabia, Johnson underplayed the Mecca theory of Yoruba origin (Johnson 1921:6-7). Muhammad also said that the ancestors of the Yorubas or Oduduwa might not have hailed from Mecca but a city near Mecca called Mondiana: a city famous for apostasy mentioned in the Koran, called Madyan (Qur'an, 7:85-93; Muhammad 2013:9). The conceptualisation of Oduduwa in the writing of the Yoruba origin has contributed to the search for the identity, the personality, the history and etymological connection with the Yoruba people. This is important because other ethnic groups like the Gas of Ghana and the Edo people of south-south Nigeria have linked their origins to Oduduwa as well (Johnson 1921:15). It is therefore pertinent to discuss Oduduwa's role in the writing of Yoruba history.

Historians are yet to conclude as to why the Yoruba oral tradition categorised the East as Mecca or Arabia. Could it be possible that the rise of Islam in Yorubaland since the 15th century played a role in their perception of the Yoruba origin (cf. Opeloye 2011:2)? Why is Oduduwa initially linked with Islam and afterwards with idolatry? Could it be possible that the 7th-century apostasy in Mecca has a link to the migration of the Yoruba ancestors to Yorubaland? Various views have linked the Arab theory of Yoruba origin with more questions that are unanswered.

\section{The debates about the theory of the Arab origin of the Yorubas}

The nature of Arabia before the rise of Islam is different from the nature of Arabia after the rise of Islam. In other words, Islam has changed the geography, the people and the belief systems of the Arabians and this continued to impact the entire world up to this day. Before the coming of Islam into the Arab world, Arabians lived in different feuding tribes and were apparently divided politically and ethnically (Watt \& Cachia 2020:1). Idolatry was practised amongst many Arabs before the emergence of Islam. Their political unity came into existence sometime around 634 to $750 \mathrm{AD}$ (Watt \& Cachia 2020:1). The Prophet Mohammed who founded Islam made no provision for a successor and after he died on 08 June 632 AD (United Church of God 2007:29), many tribes in Arabia debated amongst each other to support certain candidates that were to succeed the prophet. One of the contending candidates was Ali ibn Abi Talib, who was the first cousin and adopted son of Prophet Mohammed. Ali was also Mohammed's second convert 
after Khadija, the prophet's first wife. Abu Bakr, the father of Mohammed's favourite wife Ayesha and one of the earliest converts of the prophet, was chosen to succeed Mohammed (United Church of God 2007:30) for many reasons, most notably his commitment to the paying of the arms-tax that was required of every Muslim (Patel 2001:4).

Furthermore, some tribal groups in Mecca rebelled against the selection of Abu Bakr to succeed Prophet Mohammed. The Quraysh tribe in Mecca remained committed to Abu Bakr unlike the Ghatafan, the Hawazin and the Tayy tribes from central, east and south Arabia (Muhammad 2013:7). Patel said that their reason for pledging allegiance to $\mathrm{Abu}$ Bakr was for them to continue to exercise political control over Mecca, a renowned economic and religious centre. Others refused to pay the arms-tax whilst some claimed that their political allegiance was to the late Prophet Mohammed and not to Abu Bakr. Those that rebelled against Islam and against $\mathrm{Abu}$ Bakr, together with all those that initially rebelled against the Prophet Mohammed, were tagged 'apostates' (Patel 2001:5). Patel (2001) said that some of the apostates were massacred by the armies loyal to Abu Bakr, whilst many of them were chased out of Mecca and out of Arabia in what is referred to as the 'ridda war' (p. 5).

Some of the apostates included Maslama, Talhah, Sajah bint al-Harit, Tulaya of Banu Assad and many more. In an effort to defend the theory of apossible migration of the Arabs to Yorubaland, Muhammad said that al-Harit originated from a sub-tribe of the Arabs called the Banu Yarba and there is no proof that the name Yarba could be associated with the Yoruba people of West Africa. He further said that Maslama or Musaylimah's character could be compared with that of Oduduwa, both of whom were skilled magicians who apostatised. Muhammad states that Abu Bakr succeeded in reintegrating many apostatising tribes and integrated them into the Muslim polity in Mecca (Muhammad 2013:8). However, Patel (2001) noted that the apostatising tribes that left Mecca were chased through Bahrain, Oman, Yemen and all other parts of Arabia converting its people to become Muslims (p. 5).

Oduduwa is not clearly mentioned amongst those who left Mecca or Arabia as apostates. Wesley Muhammad is of the opinion that around the 7th and 9th centuries, some of the apostates mentioned and some unknown might have migrated to West Africa and to Oyo in particular. He did not support the Oduduwa migration legend, but he is of the view that the historical reality of the ridda war does lend support to a possible migration of some Arabs to Oyo: '[d]espite some modern, scholarly cynicism, the basic story [ridda war] no doubt reflects real historical development [in connection with the Yoruba migration from Arabia]'3 (Muhammad 2013:18). Although he admits, there are no Arab-Muslim sources that support this conjecture (Muhammad 2013:8). Johnson (1921) also said that there is no Arab record to 3.My emphasis support the theory of the migration of the Arabs to Yorubaland, shortly after the death of Prophet Mohammed (p. 5).

The Yorubas are mostly dark-skinned people, and they take pride in associating with the colour black, regarding it as a stamp of beauty. The word Oduduwa originates from the Yoruba word dudu which means black (Ellis 1966:41-42). There were possibly black people in the Arabian, pre-Islamic period, most of whom might have originated from Ethiopia (Hunwick 2005:103; Muhammad 2013:29). In fact, the first muezzin (someone who calls and leads to prayer in the mosques) in Islam is an Abyssinian freedman called Bilal, whose freedom was negotiated for by Prophet Mohammed and Abu Bakr. Moreover, because Prophet Mohammed had good relations with Ethiopia, it is alleged that the emperor of Ethiopia during the time of the Prophet provided refuge to many Muslims that were persecuted. The Prophet had also called upon Muslims not to discriminate against others because of their skin colour (Hunwick n.d:1-2; Kor'an, 33:50). Distinguishing the Yoruba ancestors amongst the apostate that left Arabia from the 7th through the 9th centuries suggests that they could have been darkskinned people. The question arises: were there Arabs of African origin that migrated to Yorubaland soon after the death of Prophet Mohammed?

It is important to note that during and after the time of the Prophet Mohammed, the black people in Arabia were mostly slaves: ' $[\mathrm{t}]$ he Arabs had black Africans living among them from before the days of Islam - mainly it would appear as slaves' (Hunwick n.d.:4). The Hamitic myth had also contributed in making some Arabs to equate the blackskinned with slavery (Hunwick n.d.:1-2). The myth posits that the people or races from the ancient Near East, including the Arabs, are intellectually superior or more advanced than Africans or dark-skinned people of African descent (Sanders 1969:521). There is an ancient Greek reflection shared amongst the people of the Mediterranean according to which the world is divided north of the Equator into seven latitudinal zones where it is postulated that the hotter the climate, the less civilised its people. Africans are classified as being located in zone one, said to be the hottest area and thus, they are assumed to be intellectually weak for reasons of the hot climate (Hunwick n.d:7-8).

In addition, these negative perceptions about Africans in ancient Arabia suggest that their acceptance or nonacceptance of Islam would not have been very significant to the Muslim communities after the ridda. They would not have been pursued outside of Arabia in the way Oduduwa was followed to Ile Ife by Sahibu. David Siddhartha Patel noted that the various civil conflicts amongst the Arabs after the ridda did not lead to a mass exile of the Arab people out of Arabia. Instead, the tribes fought over leadership and yet lived together: '...tribes did not revolt against Islam and leave the Muslim community; they only fought over the leadership of it' (Patel 2001:3). 
The perception of Africans in Arabia as inferior people suggests that they would not have rejected Islam, the religion of their masters when it was preached to them. Slaves were trained to obey their masters. Moreover, the black Arabian slaves would have preferably migrated to Ethiopia or along the North African axis, and even if they came to Ile Ife, they would have easily been subdued by the people of Ile Ife. If Oduduwa was a black person from Arabia, how did he become a prince or his father Lamurudu a king in a country or region that harboured stereotypes against black skin? Oduduwa or the ancestors of the Yorubas returned to idolatry in Arabia, which makes it easy to speculate that Mecca was known for idolatry in the pre-Islamic period. Hence, it may be postulated that the alleged Yoruba ancestors could have been Arabs and not people of African descent, as Wesley Muhammad had suggested (cf. Muhammad 2013:29-30).

Wesley Muhammad further noted that the bards or arokins Johnson interviewed between 1887 and 1897 were neither Muslims nor Christians and yet they regarded Oduduwa as an apostate from Mecca. The 1988 arokins of Oyo slightly changed the Oduduwa myth and said that he was not an apostate, but had a confrontation with his brother and left Arabia voluntarily for Ile Ife (Muhammad 2013:9-10). Considering the stereotype against Africans in Arabia just after the ridda, the alleged ancestors of the Yoruba or Oduduwa would have focussed on uniting himself with any of his relatives or family member, a common practice amongst the persecuted to unite and face their oppressor rather than to fight amongst themselves. This does not, however, preclude that all Arabs perceived the black people as slaves: 'Arabs had no grounds for assuming that all black people were justifiably to be seen as slaves' (Hunwick n.d.:1).

On the subject of culture, there are few similarities between the Yoruba culture and those of the Arabs. On the contrary, there are many differences. Opeloye cited similarities in marriage between Yoruba and the Islamic injunctions (Opeloye 2011:4-8), whilst Agai noted that the extravagant Yoruba burial rituals are incomparable to the Islamic or Arab simple funeral burial processions for the dead (Agai 2015:444). Adeyemi said that there are certain words in the Yoruba language that have similarities in meaning and pronunciation with Arabic and yet, there are more words that are different in the two languages. He observed that in the Yoruba language it is difficult to vowelise all the Arabic words and to stop on consonant words, citing the example of the Arabic word for 'Qur'ān/Koran' and for the Yoruba 'Kurāni' (Adeyemi 2016:221). Adeyemi thought that certain similarities in meaning between two ethnic groups suggest that history might have connected the two at some point in time 'the comparison of Arabic and Yoruba languages show that the diffusion of Arabic to Yoruba may be attributed to historical connections between the people of Yoruba and the Arab' (Adeyemi 2016:224). Considering the similarities between two cultures, it is difficult to ascertain whether one of the cultures and its people might have originated from the other.
Olumide Lucas has argued that the many similarities in the pronunciation and meanings of words in the language of the Yorubas and the ancient Egyptians suggest that the Yorubas originated from Egypt, or that the Yorubas were influenced by the Egyptians. He said the word 'Khu' or ' $\mathrm{Ku}$ ' in ancient Egyptian language meant 'he or she dies' (Lucas 1948:261). Although the word 'Khu' or ' $\mathrm{Ku}$ ' also means 'he or she dies' in the language spoken by the Berom people of north-central Nigeria, as yet there has been no claim that the Berom people originated from Egypt (Agai 2016:186). The existence of cognate words between the Yoruba and Arabic languages is not sufficient evidence to conclude that the Yoruba originated from Arabia. The effects of the ridda war, the contentions of the skin colour of the Yorubas and those of the Arabs and the arguments suggesting a link between the Arabian culture and language with those of the Yorubas foster more questions about the originality and the reliability of the view that the Yorubas originated from Arabia.

\section{Conclusion}

It is not clearly known when Islam found its way into Yorubaland, as it was unplanned and unannounced (Gbadamosi 1978:4). The Arabs came to Yorubaland in the 14th and 15th centuries for trade and for Islamic evangelism, but their activities were not officially recorded until the 18th century when the Hausa-Fulani people from northern Nigeria began to preach Islam in Yorubaland (Opeloye 2011:2). There is little or no record that the Arabs who initiated Islam in Yorubaland were darkskinned people like the original Yorubas were. The Yorubas followed their traditional religions before the 14th century when Islam allegedly arrived in Yorubaland. There is no record that the ridda war in Arabia had a direct and immediate impact on the Yorubas in Yorubaland around the 7th and 9th centuries when the alleged apostates began to leave Mecca and Arabia. The debatable identity, personality and character of Oduduwa in connection with Islam and idolatry suggest that Oduduwa might not have promoted Islam and by implication, nor does he promote the theory of an Arab origin of the Yorubas in Yorubaland.

Whilst this research highlights a few weaknesses of the theory of the Arab origin of the Yorubas, it does not in any way argue in favour of an Egyptian origin of the Yorubas. Archaeological evidence in support of a possible migration of Arabs and Egyptians to Yorubaland are scant, or unavailable (cf. Bowers 1985:2). At present, it has not been proven that the Negro skeletal remains found in Iwo Eleru (Yorubaland) in 1965, associated with the microlithic industry, is that of a Yoruba person. Moreover, no one is certain about the lineage of the remains, be it of Arab, Egyptian, Nigerian origin, or somewhere else (Clark 1970:165; Falola \& Heaton 2010:19; Omolewa 2008:15). Although archaeologists have in the 1930s found some Nubian artefacts and remains of a Nubian monastery in Sudan near the Chadian border and the northern part of the Lake Chad, the findings did not connect 
the Yoruba genealogy with the Nubian or Coptic Christians. Instead, the findings provide some information that Christians came to Borno and other parts of northern Nigeria even before they came to southern Nigeria in the 1540s (Agai 2016:134-135; Bowers 1985:4).

In addition, the linguistic and other similarities in cultural beliefs and practices between the Yorubas and the Arabs or between the Yorubas and the Egyptians emphasised by Lucas (1948:21-30, 36-36, 261), Opeloye (2011:4-8) and Johnson (1921:5-6) did not provide adequate evidence to propose or argue for an Arab origin of the Yoruba. More differences seemed to exist between these cultures (cf. Agai 2015:444). These archaeological and anthropological weaknesses about the Arab theory of the Yoruba origin suggest that the theory might not be taken seriously until further investigation provides evidence to the contrary. It is not surprising that many scholars like Johnson, Frobenius, Lucas, Folorunso and others downplayed the theory of the Arab origin of the Yoruba. Their perception of the 'East' might have been Egypt or another region of the ancient world, but not Arabia.

\section{Acknowledgements}

I wish to appreciate the following scholars for the professional academic advice they provided during the writing of this research: Eugene Musa Dido (Department of History and International Relations, Plateau State University Bokkos), Peace Danjuma (Department of History and International Relations, Plateau State University Bokkos) and Chimkaodinaka David (Department of Archaeology and Heritage Studies, University of Jos). The School of Religion, Philosophy and Classics, University of KwaZulu-Natal sponsored this research, I thank you.

\section{Competing interests}

The author declares that no competing interest exists.

\section{Author's contributions}

The author declares that he is the sole author of this research article.

\section{Ethical consideration}

The article complied with all ethical standards without any intention to hurt any group or their belief systems.

\section{Funding information}

This research has been funded by the School of Religion, Philosophy and Classics, University of KwaZulu-Natal.

\section{Data availability statement}

Data sharing is not applicable to this article as no new data were created or analysed in this study.

\section{Disclaimer}

The views and opinions expressed in this article are those of the author and do not necessarily reflect the official policy or position of any affiliated agency of the author.

\section{References}

Adeyemi, K.A., 2016, 'A study of the relationship between Arabic and Yoruba languages', Open Journal of Modern Linguistics 6(3), 219-224. https://doi. org/10.4236/ojml.2016.63023

Afolayan, F.O., 1993, Reconstructing the past to reconstruct the present: The nineteen century wars and Yoruba history, viewed 16 October 2015, from http://quod.lib. umich.edu/p/passes/4761530.0006.008/.

Agai, J.M., 2015, 'Rethinking Yoruba culture in the light of Yoruba origins', Journal for Semitics 24(2), 427-450. https://doi.org/10.25159/1013-8471/3461

Agai, J.M., 2016, 'Samuel Johnson on the egyptian origin of the Yoruba', PhD dissertation, School of Religion, Philosophy and Classics, University of KwaZuluNatal, Pietermaritzburg.

Akintoye, S.A., 2004, 'From early time to the 20th century', in N.S. Lawal, M.N.O Sadiku \& A. Dopamu (ed.), Understanding Yoruba life and culture, pp. 3-30, African World Press, Trenton, NJ.

Aliogo, J.E., 2012, Up to date current affairs, Dejoe Publication, Enugu.

Amy, Y.J., 2016, Sultanate of Sokoto (Sokoto Caliphate), viewed 12 June 2014, from http://www.blackpast.org/gah/sultanate-sokoto-sokoto-caliphate.

Awolalu, O.F., 1979, Yoruba beliefs and sacrificial rites, Longman Group Limited, London.

Ayandele, E.A., 2004, 'Yorubaland up to 1800', in I. Obaro (ed.), Groundwork of Nigeria history, pp. 121-143, Heinemann Educational Books, Jos.

Biobaku, S., n.d., The pattern of Yoruba history, pp. 63-67, viewed 12 June 2014, from www. patternofyorubahistory.com.

Bowers, P., 1985, 'Nubian Christianity: The neglected heritage', Africa Journal of Evangelical Theology 4(1), 1-11.

Clapperton, H., Denham, D. \& Oudney, W., 1826, Narrative of travels and discoveries in Northern Nigeria and central Africa in the years 1822-1823, and 1824, John Murray, London.

Clark, J.D., 1970, The prehistory of Africa: Ancient peoples and places, G. Daniel (ed.), vol. 72, Thames and Hudson, London.

Ellis, A.B., 1966, The Yoruba-speaking peoples of the slave coast of West Africa, their religion, manners, customs, laws, language, etc., Anthropological Publishers, Oosterhout.

Falola, T., 1999, Yoruba gurus: Indigenous production of knowledge in Africa, African World Press, New Jersey, NJ.

Falola, T. \& Heaton, M.M., 2010, A history of Nigeria, Cambridge University Press, Cambridge.

Folorunso, C.A., 2003, 'Views of ancient Egypt from a West African perspective' in D.O. Connor \& A. Reid (eds.), Ancient Egypt in Africa, pp. 77-94, University College London (UCL), London.

Frobenius, L., 1913, The voice of Africa: Being an account of the travels of the German inner African expedition in the years 1910-1912, vol. 1, Benjamin Blom New York, NY.

Gbadamosi, T.G.O., 1978, The growth of Islam among the Yoruba, 1841-1908, Longman Group Limited, London.

Hunwick, J.O., 2005, 'A region of the mind: Medieval Arab views of African geography and ethnography and their legacy', Sudanic Africa 16(2005), 103-136.

Hunwick, J.O., n.d., Arab view of black African and slavery, viewed 26 June 2020, from http://glc.yale.edu.

Johnson, S., 1921, The history of the Yorubas: From the earliest times to the beginning of the British protectorate, O. Johnson (ed.), Church and Schoo Suppliers, Abuja.

Kolapo, F.J., 2010, 'The southward campaigns of nupe in the Lower Niger Valley', in P.E. Lovejoy (ed.), Slavery on the frontiers of Islam, pp. 69-86, Markus Wiener Publisher, Princeton, NJ.

Lange, D., 2011, 'Origin of the Yoruba and "The lost tribes of Israel"', Anthropos 106(2), 579-595. https://doi.org/10.5771/0257-9774-2011-2-579

Lucas, J.O., 1948, The religion of the Yorubas: Being an account of the religious beliefs and practice of the Yoruba peoples of southern Nigeria, especially in relation to the religion of ancient Egypt, C.M.S. Bookshop, Lagos.

Lucas, J.O., 1970, Religions in West Africa and ancient Egypt, n.p., Lagos.

Muhammad, W., 2013, Ifa and Islam as sibling rivals: The black Arabian origins of the Yoruba, Truth of God Institute, viewed 24 June 2020, from https://www.academia. edu/5030583/The Black Arabian Origins of the Yor\%C3\%B9b\%C3\%A1 and

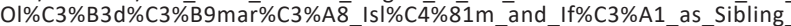
Rivals.pdf.

Oates, J., 1979, Babylon with 137 illustrations: Ancient peoples and places, Thomas and Hudson, London.

O'Connor, D. \& Reid, A., 2003, 'Locating ancient Egypt in Africa: Modern theories, past realities', in D. O'Connor \& A. Reid (eds.), Ancient Egypt in Africa, pp. 1-21, University College London (UCL), London. 
Ojo, A., 1999, Yoruba Omo Oduduwa: Papers on Yoruba people, language, and culture, viewed 09 June 2008, from http://www.uga.edu/aflang/YORUBA/ ODUDUWA.htm.

Olojede, F., 2011, 'The exodus and identity formation in view of the Yoruba origin and migration narratives', Scriptura 108(2011), 342-356. https://doi.org/ 10.7833/108-0-7

Olupona, J.K., 1993, 'The study of Yoruba religious tradition in historical perspective', NUMEN 3(40), 240-273. https://doi.org/10.1163/156852793X00176

Omolewa, M., 2008, Certificate history of Nigeria, Longman, Ikeja.

Opeloye, M.O., 2011, 'The Yoruba Muslims' cultural identity question', Ilorin Journal of Religious Studies 2(1), 1-20.

Oyebade, A., 2004, 'Reconstructing the past through oral tradition,' in N.S. Lawal, M.N.O. Sadiku \& A. Dopamu (eds.), Understanding Yoruba life and culture, pp. 51-62, African World Press, Trenton, NJ.

Parrinder, G., 1951, West African psychology: A comparative study of psychological and religious thought, Lutterworth, London.
Pate, M.C. \& Hays, J., 2003, Iraq: Babylon of the end-times?, Bakerbook, Grand Rapids, MI.

Patel, D.S., 2001, Political engineering and origins of culture: The institutional foundations of the rise of Islam, pp. 1-34, Research Project, Department of Political Science, Stanford University.

Quadri, Y.A., 1986, 'An appraisal of Muhammad Bello's Infaqul-Mansur Fi Tarikh Bildadi T- Takrur', Journal of Arabic and Religious Studies 3, 53-62.

Sanders, E.R., 1969, 'The Hamitic Hypothesis: Its origin and functions in time perspective', The Journal of African History 10(4), 521-532. https://doi org/10.1017/S0021853700009683

Sundkler, B. \& Steed, C., 2000, A history of the Church in Africa, Cambridge University Press, Cambridge.

United Church of God, 2005, The Middle East in Bible prophesy, pp. 1-78, United Church of God, Cincinnati, OH.

Watt, W.M. \& Cachai, P., 2020, Who is an Arab?, viewed 08 July 2020, from https:// www.africa.upenn.edu/K-12/Who_16629.html. 